\title{
Estimate of consumption of phenolic compounds by Brazilian population
}

\author{
Estimativa do consumo de compostos \\ fenólicos pela população brasileira
}

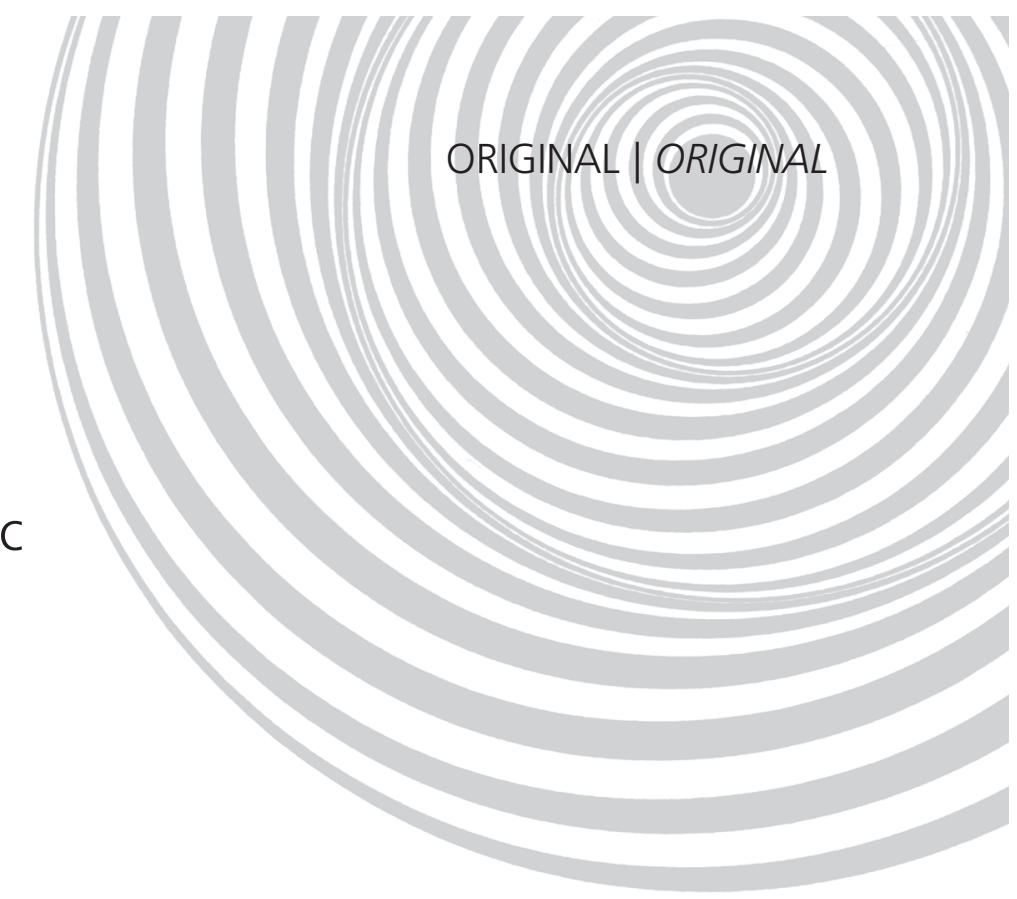

Vanesa Gesser CORRÊA ${ }^{1}$

Camila TURECK ${ }^{1}$

Gelvani LOCATELI'

Rosane Marina PERALTA²

Eloá Angélica KOEHNLEIN ${ }^{1}$

A B S T R A C T

\section{Objective}

Estimate the intake of phenolic compounds by the Brazilian population.

\section{Methods}

To estimate the average per capita food consumption, micro data from the National Dietary Survey and from the Household Budget Survey from 2008 to 2009 was analyzed. The phenolic content in food was estimated from the base of Phenol-Explorer. It was chosen according to compatibility and variety of food items and usual method of preparation.

\section{Results}

The Brazilian population consumed, on average, $460.15 \mathrm{mg} /$ day of total phenolic compounds, derived mainly from beverages (48.9\%), especially coffee and legumes (19.5\%). Since this analysis of classes of phenolics it was possible to observe an intake of $314 \mathrm{mg} /$ day of phenolic acids, $138.92 \mathrm{mg} / \mathrm{day}$ of flavonoids and $7.16 \mathrm{mg} /$ day of other kinds of phenolics. Regarding the variables studied this present study shows that those men who live in the countryside and in the northeastern region of the country had a higher consumption of phenolic compounds. Besides, consumption was higher by adults and the elderly, the medium income classes, the population with incomplete and complete primary education and those with adequate nutrition and also overweight status.

\section{Conclusion}

The intake of phenolic compounds can be considered low, especially where consumption of fruit and vegetables is insufficient. We can conclude that coffee and black beans were the best contributors to phenolic intake.

Keywords: Antioxidants. Flavonoids. Food consumption. Phenolic compounds.

${ }^{1}$ Universidade Federal da Fronteira do Sul, Curso de Nutrição. R. Edmundo Gaievski, 1000, Rodovia PR 182, Km 466, 85770-000, Realeza, PR, Brasil. Correspondência para/Correspondence to: EA KOEHNLEIN. E-mail: <eloa.koehnlein@uffs.edu.br>.

2 Universidade Estadual de Maringá, Curso de Bioquímica, Departamento de Bioquímica. Maringá, PR, Brasil. 


\section{R E S U M O}

\section{Objetivo}

Estimar o consumo de compostos fenólicos pela população brasileira.

\section{Métodos}

Para estimativa do consumo alimentar médio per capita foram analisados os microdados do Inquérito Nacional de Alimentação, da Pesquisa de Orçamentos Familiares 2008-2009. O teor de fenólicos dos alimentos foi estimado a partir da base de dados Phenol-Explorer, considerando a espécie e variedade do alimento e o modo de preparo habitual de consumo.

\section{Resultados}

A população brasileira consumiu em média 460,15 mg/dia de compostos fenólicos totais, provenientes principalmente das bebidas (48,9\%), com destaque para o café, e leguminosas (19,5\%). A análise do consumo por classes de fenólicos possibilitou observar uma ingestão de 314 mg/dia de ácidos fenólicos, 138,92 mg/dia de flavonoides e 7,16 mg/dia de outros fenólicos. Com relação às variáveis estudadas, os homens e os indivíduos residentes na zona rural e na região nordeste do país apresentaram maior consumo de compostos fenólicos. Além disso, destacaram-se também os adultos e idosos, as classes de rendimento medianas, a população com ensino fundamental completo ou incompleto e os indivíduos eutróficos e com excesso de peso.

\section{Conclusão}

A ingestão de fenólicos totais pode ser considerada baixa, especialmente em razão do consumo insuficiente de frutas e hortaliças. Ressalta-se que o café e o feijão preto foram os principais alimentos contribuintes para o consumo de fenólicos da população brasileira.

Palavras-chave: Antioxidantes. Flavonoides. Consumo alimentar. Compostos fenólicos.

\section{INTRODUCTION}

Several studies have highlighted the inverse association between the consumption of plant foods and the prevalence of noncommunicable chronic diseases such as cancer, diabetes, cardiovascular diseases and degenerative diseases ${ }^{1-6}$. The benefits are related to the presence of bioactive compounds with antioxidant activity, which are capable of neutralizing the so-called free radicals. These unstable molecules even attack a human cell on average $10^{5}$ times every day, causing damage in structures such as membranes, nucleic acids, proteins and polysaccharides ${ }^{7,8}$.

In addition to the primary line of defense performed by endogenous enzymes, antioxidants from food greatly assist in the neutralization of free radicals. The main dietary antioxidants are represented by vitamins: A, C and E; carotenoids; minerals: zinc, selenium, manganese and copper and phenolic compounds 9 .
The daily intake of phenolic compounds is considerably higher than the daily intake of other dietary antioxidants, such as carotenoids and vitamins $C$ and $E$. In accordance with PerézGimenéz et $a l .{ }^{10}$, while the phenolic intake is on average $1 \mathrm{~g} /$ day, the intake of antioxidant vitamins is $110 \mathrm{mg} /$ day and of beta-carotene is $9.4 \mathrm{mg} /$ day. Furthermore, the phenolic compounds present a higher antioxidant capacity compared with vitamins and carotenoids, representing $90 \%$ of total antioxidant intake ${ }^{11,12}$.

It is also important to note that in addition to antioxidant activity, phenolic compounds perform other actions in the organism, such as vasodilator, anti-inflammatory, anti-atherogenic and antithrombotic and also act as modulators of enzymatic pathways, of gene expression, improve the properties of cell membrane and receptors function ${ }^{13-15}$.

Phenolic compounds are widely distributed in all plants and represent the largest group among bioactive compounds found in vegetables. Among the foods rich in phenolic compounds are 
included cocoa, red wine, pomegranates, berries, tea, coffee, citrus fruits and walnuts ${ }^{16,17}$.

According to their chemical structure, phenolic compounds are divided into classes, as follows: phenolic acids, stilbenes, coumarins, lignins, tannins and flavonoids ${ }^{17}$. Among these classifications, phenolic acids and flavonoids are considered the most common ${ }^{18}$.

Flavonoids stand out as the largest class of phenolics present in plants, where have been identified over 5,000 compounds, and they may be divided into six subgroups according to their chemical structure: flavonols, flavones, flavanols, flavanones, anthocyanins and isoflavones ${ }^{17,19}$.

Phenolic acids can be divided into hydroxycinnamic acids and, hydroxybenzoic acids $^{19}$. The hydroxycinnamic acids are found in large amounts in foods such as coffee, leafy as chicory, olives and cereals such as corn and wheat (after hydrolysis). The hydroxybenzoic acids have as food sources tea, wine and chestnuts ${ }^{20}$. Among the total phenolics, phenolic acids stand out as the class of higher consumption. It is estimated that in Europe $58 \%$ of the intake of phenolic compounds are from this class ${ }^{21}$.

The identification of dietary sources of phenolic compounds is necessary in order to understand and explore the effects of health promotion as well as deepen knowledge about these foods ${ }^{20}$. In Brazil, studies that have sought to quantify the consumption of these compounds, or identify foods of Brazilian usual diet that are sources of it, are scarce $22-24$.

Thus, the objective of this study was to estimate the population's intake of total phenolics, considering variables such as gender, household status, the regions of the country, age group, education, nutritional status and income groups and, also, assess what are the food and/or food groups that contribute most to this intake.

\section{METHODS}

For this study were analyzed data from the Inquérito Nacional de Alimentação (INA, National
Dietary Survey) of the Pesquisa de Orçamentos Familiares (POF, Household Budget Survey) 20082009. Until POF 2002-2003 were only surveyed data on household food availability, making it impossible to evaluate the actual food consumption of the population. As a result, in the last POF (2008-2009) it was first carried out a survey on food intake in a subsample of 13,569 randomly selected households, which corresponded to $24.3 \%$ of the 55,970 households surveyed in 2008-2009. The data relating to food consumption were collected from 34,003 residents aged 10 or older considering the type of preparation, the measure used, the amount consumed, consumption time and if it occurred at home or away from home 25 .

Data from individual food intake were surveyed throughout the year when was carried out the research, during two non-consecutive days, being notes taken by the informants themselves and supplemented by interviews conducted by research agents. The informants received an instructional material that included photographs of utensils and bottles often used to serve food and beverages ${ }^{25}$.

The foods named by the informants were classified into 21 groups, and were considered the item information separately or in conjunction with similar foods that were reported at least by 100 individuals on the first day of food record. The items consumed by less than 100 people were gathered in a category labeled 'other'. The quantities of food in home cooking measurements were converted into grams or milliliters and for the estimates of the average food consumption were used the first record day data, since the quality of information exceed the following days ${ }^{25-27}$.

Research microdata, provided by the Instituto Brasileiro de Geografia e Estatística (IBGE, Brazilian Institute of Geography and Statistics), were obtained considering the following variables: per capita food consumption, gender, household status, geographic region, age group, income class, education, weight and height. 
For each listed food its usual method of preparation for consumption was identified. In addition, for the categories of POF (2008-2009) described as preparations based on the main food was considered. For preparations the ingredient with the highest content and its proportion used into taken into account. To estimate the phenolic content of the food consumed the database Phenol-Explorer (http://www.phenol-explorer.eu) was used as well as scientific articles for food that did not have their contents available in the main source of research. These were chosen according to the species and variety compatibility of the analyzed food $28-30$.

Phenol-Explorer is a database, launched in 2009, which provides the content of 502 phenolics in 452 foods $^{4}$. The data relating to phenolic content are made available through five different analytical methods: chromatography, High Performance Liquid Chromatography (HPLC) after hydrolysis, normal phase HPLC, FolinCiocalteu and differential $\mathrm{pH}^{4}$.

For the determination of phenolic content of the food consumed by the Brazilian population there was the exclusion of foods containing only traces of phenolics or that did not contain these compounds, as well as those of animal origin. Further, in order to approximate the estimate of usual consumption, for foods that are commonly eaten in the cooked form a yield factor available at Phenol-Explorer database was used. Thus, 51 foods were totaled to calculate the consumption of phenolic compounds.

Regarding the methods for determining the amount of phenolic compounds present in foods in accordance with the Phenol-Explorer, the following criteria were adopted: for cereals preference for HPLC after hydrolysis was given, and for the items that did not have data by this method and for other foods the normal phase chromatography was used. For each food, according to the database, the content of phenolic acids, flavonoids and other phenolics was determined and with the sum of it the total phenolics of each food item was quantified.
After the analysis of phenolic content of the main plant foods that compose the Brazilian diet, the sum of all these compounds consumed per day was calculated. From these data the percentage of representativeness of the food groups and/or foods in the total amount of ingested phenolic compounds was calculated.

The estimate of the phenolic content was held, also, considering the variables available on microdata from the survey: age, education, gender, geographic region, household situation (urban or rural) and income. The content was also estimated according to the nutritional status of the individuals, using the Body Mass Index (BMI). Reference standards and classification criteria from Onis ${ }^{31}$, World Health Organization (WHO) ${ }^{32}$ and Nutrition Screening Initiative (NSI) ${ }^{33}$ were used for adolescents, adults and the elderly, respectively.

Data were organized and analyzed using Microsoft Excel ${ }^{\circledR} 2010$ software and statistical programs GraphPad Prism ${ }^{\circledR} 5$ and Sisvar 5.3, being expressed as mean, standard deviation and contribution percentage of the food groups and foods in relation to the total content of phenolics.

The Student's $t$ test was used for comparison of the two variables with $5 \%$ of significance. The Analysis of Variance (Anova) was used to compare three or more variables and when significant differences were found the Bonferroni $t$ test was applied with $5 \%$ significance level.

\section{R E S U L T S}

The characteristics of the studied population can be seen in Table 1. With regard to age, the adult population was the largest group of participants (66.8\%) of this study. The energy consumption average was $2000 \mathrm{kcal}$ for men and $1700 \mathrm{kcal}$ for women, $56.0 \%$ of this total came from carbohydrates, $16.0 \%$ from proteins and $27.0 \%$ from lipids ${ }^{19}$. With respect to fibers, the highest consumption was observed in males, especially in adults. 
The average intake of total phenolics by the Brazilian population was $460.15 \mathrm{mg} /$ day (Table 2 ), being beverages (48.90\%) and legumes $(19.50 \%)$, especially coffee and black beans, the main foods contributing to this intake. Cereals and products and fruits contributed with $16.64 \%$ and $9.38 \%$, respectively, and the boiled corn and apple the foods with highest importance. The other food groups represented $5.40 \%$ of the total intake of phenolics.

Table 1. General and diet characteristics of the Brazilian population* (Household Budget Survey 2008-2009) $(n=33,847)$.

\begin{tabular}{|c|c|c|c|c|c|c|}
\hline \multirow[b]{2}{*}{ Characteristics } & \multicolumn{3}{|c|}{ Male } & \multicolumn{3}{|c|}{ Female } \\
\hline & Adolescent & Adult & Elderly & Adolescent & Adult & Elderly \\
\hline $\mathrm{n}$ & 3,402 & 10,220 & 1,986 & 3,508 & 12,410 & 2,321 \\
\hline Weight (kg) & 51.31 & 73.42 & 69.57 & 48.17 & 61.97 & 63.06 \\
\hline BMI $\left(\mathrm{kg} / \mathrm{m}^{2}\right)$ & 19.93 & 25.24 & 25.26 & 20.20 & 25.33 & 26.61 \\
\hline Energy intake (kcal) & $2,136.50$ & $2,163.00$ & $1,795.00$ & $1,911.50$ & $1,710.00$ & $1,490.00$ \\
\hline Carbohydrate intake (g) & 301.35 & 296.20 & 248.40 & 273.50 & 240.50 & 210.90 \\
\hline Protein intake(g) & 83.95 & 91.50 & 77.40 & 72.15 & 70.10 & 62.90 \\
\hline Lipid intake(g) & 66.35 & 65.40 & 53.40 & 59.35 & 52.30 & 44.60 \\
\hline Fiber intake(g) & 21.90 & 23.50 & 21.50 & 18.65 & 18.20 & 17.60 \\
\hline
\end{tabular}

Note: *Values expressed as mean. BMI: Body Mass Index.

Source: Household Budget Survey 2008-2009: analysis of individual food consumption in Instituto Brasileiro de Geografia e Estatistica25, coordination of work and income.

Table 2. Estimated intake of total phenolics, phenolic acids, flavonoids and other phenolics by food group and percentage of contribution of major food sources (Household Budget Survey 2008-2009).

\begin{tabular}{|c|c|c|c|c|c|c|c|c|c|c|c|c|c|}
\hline \multirow[b]{2}{*}{ Food groups } & \multicolumn{3}{|c|}{ Total phenolics } & \multicolumn{3}{|c|}{ Phenolic acids } & \multicolumn{3}{|c|}{ Flavonoids } & \multicolumn{3}{|c|}{ Other phenolics } & \multirow{2}{*}{$\begin{array}{l}\text { Major food source (\% } \\
\text { contribution to the phenolic } \\
\text { intake for each food group) }\end{array}$} \\
\hline & $M$ & \pm & SD & M & \pm & SD & M & \pm & SD & $M$ & \pm & SD & \\
\hline Beverages & 225.36 & \pm & 191.01 & 198.14 & \pm & 181.42 & 21.77 & \pm & 41.29 & 5.45 & \pm & 65.64 & $\begin{array}{l}\text { Coffee (83.58), orange juice } \\
(12.89), \text { mate tea }(2.46) \text {. }\end{array}$ \\
\hline Legumes & 89.70 & \pm & 90.61 & 38.11 & \pm & 38.01 & 51.58 & \pm & 52.77 & - & \pm & - & $\begin{array}{l}\text { Black bean (93.75), bean } \\
\text { preparations ( } 5.46) \text {. }\end{array}$ \\
\hline $\begin{array}{l}\text { Cereals and } \\
\text { products }\end{array}$ & 77.04 & \pm & 181.50 & 73.65 & \pm & 181.60 & 2.31 & \pm & 5.11 & 1.15 & \pm & 2.79 & $\begin{array}{l}\text { Boiled corn }(74.60) \text {, cooked } \\
\text { rice }(9.81) \text {, glam (cornflour) } \\
(8.05) \text {, cake }(2.55)\end{array}$ \\
\hline Fruits & 43.19 & \pm & 161.99 & 0.46 & \pm & 1.27 & 42.72 & \pm & 161.48 & 0.00 & \pm & 3.65 & $\begin{array}{l}\text { Apple (34.64), açai (33.85), } \\
\text { orange (20.58), grape } \\
(3.77) \text {. }\end{array}$ \\
\hline $\begin{array}{l}\text { Cocoa-based } \\
\text { products }\end{array}$ & 19.00 & \pm & 116.79 & 0.17 & \pm & 1.44 & 18.83 & \pm & 115.72 & 0.00 & \pm & 8.02 & $\begin{array}{l}\text { Chocolate powder }(53.32) \text {, } \\
\text { Milk chocolate }(46.74)\end{array}$ \\
\hline Vegetables & 5.17 & \pm & 14.89 & 3.45 & \pm & 13.23 & 1.71 & \pm & 6.59 & 0.00 & \pm & 0.00 & $\begin{array}{l}\text { Boiled potato }(52.99), \text { kale } \\
(21.89) \text {, tomato }(6.78) \text {, } \\
\text { boiled sweet potato }(6.21) \text {. }\end{array}$ \\
\hline Oils & 0.69 & \pm & 1.50 & 0.00 & \pm & 0.01 & 0.00 & \pm & 0.00 & 0.68 & \pm & 119.58 & Heterogeneous item. \\
\hline Nuts and seeds & 0.01 & \pm & 0.20 & 0.01 & \pm & 0.20 & - & \pm & - & 0.00 & \pm & 14.73 & Heterogeneous item. \\
\hline Total & 460.15 & \pm & 341.33 & 314 & \pm & 270.01 & 138.92 & \pm & 208.06 & 7.16 & \pm & 6.57 & $\begin{array}{l}\text { Coffee (40.93), Black beans } \\
(18.27), \text { boiled corn }(12.49) \text {, } \\
\text { orange juice }(6.31) \text {. }\end{array}$ \\
\hline
\end{tabular}

Note: M: Mean; SD: Standard Deviation. 
For the consumption of phenolic acids, stood out the beverages groups (63.10\%), cereals and products (23.45\%) and legumes (12.13\%). For the flavonoids, the main contributor foods were legumes $(37.12 \%)$, fruits $(30.75 \%)$ and beverages $(15.67 \%)$. For the other phenolics, the group of beverages $(76.11 \%)$ and cereals and products $(17.06 \%)$ were the largest contributors.
The different studied variables allowed to verify that men had higher intake of total phenolics and regarding the household situation, there was a higher consumption of phenolics and subclasses in the countryside, except in relation to the other phenolics in which the consumption in the area urban was higher (Table 3).

Analysis of the intake according to the geographical regions showed that higher

Table 3. Total phenolics, phenolic acids, flavonoids and other phenolics intake by Brazilian population according to the different variables (Household Budget Survey 2008-2009)*.

\begin{tabular}{|c|c|c|c|c|c|c|c|c|c|c|c|c|}
\hline \multirow{2}{*}{ Variables } & \multicolumn{3}{|c|}{ Phenolic acids } & \multicolumn{3}{|c|}{ Flavonoids } & \multicolumn{3}{|c|}{ Other phenolics } & \multicolumn{3}{|c|}{ Total phenolics } \\
\hline & $M$ & \pm & SD & $M$ & \pm & SD & M & \pm & SD & $M$ & \pm & SD \\
\hline Total & 314.01 & \pm & 269.99 & 138.94 & \pm & 208.06 & 7.19 & \pm & 6.57 & 460.18 & \pm & 341.33 \\
\hline \multicolumn{13}{|l|}{ Gender } \\
\hline Male & 341.76 & \pm & $294.41^{a}$ & 145.99 & \pm & $204.99^{a}$ & 7.61 & \pm & $7.12^{\mathrm{a}}$ & 495.37 & \pm & $362.04^{a}$ \\
\hline Female & 290.32 & \pm & $256.88^{\mathbf{b}}$ & 132.9 & \pm & $210.46^{b}$ & 6.84 & \pm & $6.05^{b}$ & 430.06 & \pm & $319.5^{\mathbf{b}}$ \\
\hline \multicolumn{13}{|l|}{ Household status } \\
\hline Urban & 299.55 & \pm & $258.68^{a}$ & 136.54 & \pm & $193.49^{a}$ & 7.44 & \pm & $6.71^{a}$ & 443.54 & \pm & $321.63^{a}$ \\
\hline Rural & 359.14 & \pm & $298.04^{b}$ & 146.4 & \pm & $247.86^{b}$ & 6.42 & \pm & $6.06^{b}$ & 511.97 & \pm & $391.97^{b}$ \\
\hline \multicolumn{13}{|l|}{ Geographic region } \\
\hline North & 252.54 & \pm & $203.24^{\mathrm{a}}$ & 188.93 & \pm & $359.34^{a}$ & 6.93 & \pm & $6.67^{a, b}$ & 448.41 & \pm & $412.11^{a}$ \\
\hline Northeast & 376.46 & \pm & $317.25^{b}$ & 103.28 & \pm & $134.24^{a}$ & 6.96 & \pm & $5.98^{b, c}$ & 486.70 & \pm & $349.08^{b}$ \\
\hline Southeast & 300.45 & \pm & $226.11^{c}$ & 152.32 & \pm & $184.78^{c}$ & 7.29 & \pm & $6.28^{c}$ & 460.06 & \pm & $294.25^{a, c}$ \\
\hline South & 299.69 & \pm & $267.49^{c}$ & 159.06 & \pm & $204.47^{c}$ & 8.71 & \pm & $8.05^{d}$ & 467.47 & \pm & $345.03^{c}$ \\
\hline Mid West & 249.32 & \pm & $222.73^{a}$ & 139.59 & \pm & $151.23^{d}$ & 6.58 & \pm & $6.76^{a}$ & 395.51 & \pm & $282.61^{d}$ \\
\hline \multicolumn{13}{|l|}{ Age group } \\
\hline Adolescents $(\geq 10 \leq 18)$ & 275.13 & \pm & $253.43^{\mathrm{a}}$ & 158.75 & \pm & $250.18^{a}$ & 6.80 & \pm & $6.31^{\mathrm{a}}$ & 440.69 & \pm & $347.79^{a}$ \\
\hline Adults $(\geq 19 \leq 59)$ & 323.01 & \pm & $272.98^{b}$ & 136.87 & \pm & $198.31^{b}$ & 7.48 & \pm & $6.76^{b}$ & 467.36 & \pm & $340.57^{b}$ \\
\hline Elderly $(\geq 60)$ & 329.43 & \pm & $274.25^{b}$ & 118.01 & \pm & $179.05^{c}$ & 6.25 & \pm & $5.82^{c}$ & 453.70 & \pm & $333.50^{a, b}$ \\
\hline \multicolumn{13}{|l|}{ Social class (per capita income) } \\
\hline Up to U\$149.5 & 326.86 & \pm & $281.06^{\mathrm{a}}$ & 105.27 & \pm & $194.71^{\mathrm{a}}$ & 4.94 & \pm & $4.87^{\mathrm{a}}$ & 437.08 & \pm & $338.04^{\mathrm{a}}$ \\
\hline Between U\$149.5 and U\$288.4 & 367.58 & \pm & $309.64^{b}$ & 115.60 & \pm & $207.06^{a, b}$ & 6.01 & \pm & $5.32^{\mathrm{a}}$ & 489.19 & \pm & $370.25^{b}$ \\
\hline Between U\$288.4 and U\$550.0 & 343.37 & \pm & $287.73^{a}$ & 128.03 & \pm & $213.15^{b}$ & 6.57 & \pm & $5.93^{c}$ & 477.98 & \pm & $357.43^{b}$ \\
\hline More than $\cup \$ 550.0$ & 295.60 & \pm & $254.80^{c}$ & 147.46 & \pm & $206.25^{c}$ & 7.67 & \pm & $6.94^{d}$ & 450.73 & \pm & $330.76^{a}$ \\
\hline \multicolumn{13}{|l|}{ Education } \\
\hline Unschooled & 293.87 & \pm & $264.62^{a, b}$ & 146.44 & \pm & $235.53^{a, b, c}$ & 6.77 & \pm & $6.35^{a, b}$ & 447.09 & \pm & $349.13^{a, b}$ \\
\hline Incomplete primary & 358.20 & \pm & $294.36^{c}$ & 123.72 & \pm & $181.94^{\mathrm{a}}$ & 6.48 & \pm & $5.85^{\mathrm{a}}$ & 488.40 & \pm & $351.68^{c}$ \\
\hline Complete primary & 321.84 & \pm & $266.40^{b}$ & 132.67 & \pm & $195.68^{a, b}$ & 7.40 & \pm & $6.85^{b}$ & 461.92 & \pm & $337.47^{b, c}$ \\
\hline Secondary school & 289.84 & \pm & $242.57^{a}$ & 147.12 & \pm & $196.83^{b, c}$ & 8.29 & \pm & $6.99^{c}$ & 445.25 & \pm & $314.96^{a, b}$ \\
\hline Graduation & 245.69 & \pm & $212.37^{d}$ & 167.07 & \pm & $218.77^{c, d}$ & 9.45 & \pm & $8.05^{d}$ & 422.21 & \pm & $312.66^{a}$ \\
\hline Post graduation & 242.50 & \pm & $205.14^{d}$ & 182.05 & \pm & $278.11^{d}$ & 10.18 & \pm & $9.48^{e}$ & 434.73 & \pm & $342.12^{a, b}$ \\
\hline \multicolumn{13}{|l|}{ Nutritional Status } \\
\hline Underweight & 318.78 & \pm & $267.76^{\mathrm{a}}$ & 121.05 & \pm & $181.33^{a}$ & 6.22 & \pm & $5.52^{\mathrm{a}}$ & 446.12 & \pm & $330.12^{a}$ \\
\hline Eutrophic & 314.33 & \pm & $269.33^{a}$ & 141.69 & \pm & $213.26^{\mathbf{b}}$ & 7.24 & \pm & $6.68^{b}$ & 464.22 & \pm & $344.81^{b}$ \\
\hline Overweight & 312.66 & \pm & $271.89^{a}$ & 136.17 & \pm & $198.89^{b}$ & 7.27 & \pm & $5.60^{b}$ & 456.09 & \pm & $336.13^{a, b}$ \\
\hline
\end{tabular}

Note: *Values expressed as Mean (M) \pm Standard Deviation (SD); ${ }^{* *}$ Real amounts $(\mathrm{R} \$$ ) are translated into US dollars (US\$) according to the average quotation of the years 2008-2009 (US\$1 = R\$1.98). Means followed by the same letter do not differ significantly by the Bonferroni $t$ test at $5 \%$ significance. 
consumptions are not concentrated in only one location. For the intake of total phenolics stood out the northeast region $(486.70 \mathrm{mg} /$ day) followed by the south $(467.47 \mathrm{mg} /$ day) and southeast (460.06 mg/day). With respect to the classes of phenolic compounds, there was a higher consumption of phenolic acids in the northeast region ( $376.46 \mathrm{mg} /$ day), flavonoids in the north region (188.93 $\mathrm{mg} /$ day) and other phenolic in the south region ( $8.71 \mathrm{mg} /$ day).

By analyzing the intake according to age, it was noted that consumption of total phenolics was higher by adults ( $467.36 \mathrm{mg} /$ day) followed by the elderly ( $453.70 \mathrm{mg} /$ day). These also had a higher intake of phenolic acids ( $329.43 \mathrm{mg} /$ day). Intake of flavonoids was higher in the adolescent age group (158.75 mg/day) and the other phenolic in adults $(7.48 \mathrm{mg} /$ day).

In relation to income classes, the higher consumption of total phenolics and phenolic acids was observed in the intermediate classes (between U\$149,5 and U\$288.4 and U\$288.4 and $\cup \$ 550,0)$. In what concerns the consumption of flavonoids and other phenolics, these were higher in the class with higher income.

With regard to education, the highest consumption of phenolics was observed in the population with incomplete primary education ( $488.40 \mathrm{mg} /$ day), followed by the complete
(461.92 mg/day). In the class of phenolic acids, stood out the group with incomplete primary education ( $358.20 \mathrm{mg} /$ day). As for flavonoids and other phenolics the population with graduation and pos graduation had higher intake.

Regarding nutritional status, the eutrophic and overweight population had the highest intake of total phenolics, flavonoids and other phenolics (Table 3). For phenolic acids a significant difference between the different nutritional diagnoses was not found.

The estimate of intake of phenolic compounds by food groups according to the nutritional status showed that only in the intake of vegetables and cocoa-based products there was significant differences. The consumption of vegetables was higher by people with overweight and underweight and cocoa-based products was higher by eutrophic and overweight population (Table 4).

\section{DISCUSSION}

In this study we used the actual food consumption of the Brazilian population evaluated for the first time in the country to estimate the intake of phenolics. However, such estimate has limitations associated especially to the methods of evaluation of food consumption,

Table 4. Estimated total phenolic intake of the Brazilian population by food groups according to nutritional status (Household Budget Survey 2008-2009)*.

\begin{tabular}{|c|c|c|c|c|c|c|c|c|c|}
\hline \multirow{2}{*}{ Food group } & \multicolumn{3}{|c|}{ Underweight } & \multicolumn{3}{|c|}{ Eutrophic } & \multicolumn{3}{|c|}{ Overweight } \\
\hline & M & \pm & SD & M & \pm & SD & M & \pm & SD \\
\hline Cereals and products & 76.62 & \pm & $184.03^{\mathrm{a}}$ & 81.08 & \pm & $183.84^{\mathrm{a}}$ & 71.68 & \pm & $178.51^{\mathrm{a}}$ \\
\hline Vegetables & 5.00 & \pm & $13.67^{a, b}$ & 4.82 & \pm & $14.06^{\mathrm{a}}$ & 5.68 & \pm & $16.15^{b}$ \\
\hline Legumes & 89.12 & \pm & $84.31^{\mathrm{a}}$ & 90.95 & \pm & $91.75^{\mathrm{a}}$ & 88.39 & \pm & $89.97^{a}$ \\
\hline Nuts and Seeds & 0.00 & \pm & $0.16^{\mathrm{a}}$ & 0.01 & \pm & $0.17^{\mathrm{a}}$ & 0.01 & \pm & $0.24^{\mathrm{a}}$ \\
\hline Fruits & 35.27 & \pm & $137.66^{a}$ & 43.12 & \pm & $162.42^{\mathrm{a}}$ & 43.29 & \pm & $158.89^{a}$ \\
\hline Cocoa-based products & 14.53 & \pm & $98.26^{\mathrm{a}}$ & 21.21 & \pm & $125.38^{\mathbf{b}}$ & 16.25 & \pm & $105.64^{\mathrm{a}, \mathrm{b}}$ \\
\hline Oils & 0.62 & \pm & $1.53^{\mathrm{a}}$ & 0.70 & \pm & $1.51^{\mathrm{a}}$ & 0.69 & \pm & $1.49^{a}$ \\
\hline Beverages & 224.75 & \pm & $187.85^{a}$ & 222.49 & \pm & $191.15^{a}$ & 230.10 & \pm & $191.72^{a}$ \\
\hline Total & 446.12 & \pm & $330.12^{a}$ & 464.22 & \pm & $344.81^{b}$ & 456.09 & \pm & $336.13^{a, b}$ \\
\hline
\end{tabular}

Note: *388 individuals were unavailable data nutritional status. Means followed by the same letter do not differ significantly by the Bonferroni $t$ test at $5 \%$ significance.

M: Mean; SD: Standard Deviation. 
variations of the samples due to geographic and climatic factors, as well as related the bioavailability of these compounds.

The average consumption of phenolic compounds of Brazilian population ( $460 \mathrm{mg} /$ day) was lower than that found in the population of Spain (820 mg/day), Finland (863 mg/day) and France $(1193 \mathrm{mg} / \text { day })^{34-36}$. The Spanish and French studies used the same database that the present research, while the Finnish performed the dosage of the compounds by HPLC, as well as it used secondary data for the quantification. In all three studies, the HPLC method was used after hydrolysis for a greater amount of food, which can also contribute to explain the differences in the results found.

Regarding the food groups sources of phenolic compounds stood out in this research beverages (48.9\%), legumes (19.5\%) and cereals and products $(16.7 \%)$. In Spain, the group of fruits was the largest contributor (43.9\%) followed by non-alcoholic beverages (23.4\%) and vegetables $(12.6 \%)$ and in France it was observed that the major sources were non-alcoholic beverages $(55.1 \%)$, fruits $(17.2 \%)$ and alcoholic beverages $(8.2 \%)$. As regards the individual food sources, coffee was the main contributor to the intake of phenolic compounds in Brazil (40.9\%), as well as in Finland (63.3\%), France $(43.5 \%)$ and Spain $(18 \%)^{34-36}$.

The consumption of phenolic acids estimated in this research (314 mg/day) was similar to that of the Spanish population (304 mg/day) and smaller than that of France, Finland and the one found in the European Prospective Investigation into Cancer and Nutrition (EPIC) study that analyzed the consumption of 10 European countries ( $639 \mathrm{mg} /$ day, $641 \mathrm{mg} /$ day and $512 \mathrm{mg} /$ day, respectively) $)^{21,34-36}$. Coffee was the primary responsible for the intake of phenolic acids in Brazil, it also had the largest contribution to the consumption of this class in the cohorts of Spain, France, Finland and in the EPIC study. Still, stood out as other sources groups of fruits in Spain, vegetables in France, cereals in Finland and legumes in Brazil|21,34-36.
The class of phenolic acids has its consumption related to beneficial effects reported by several studies because they have a potential protective role against oxidative stress, inflammation, diabetes and cancer in experimental studies ${ }^{21}$.

Regarding flavonoids, the consumption of the Brazilian population ( $138.92 \mathrm{mg} /$ day) was lower than that of Spain (443 mg/day) $)^{34}$, France $\left(512 \mathrm{mg} /\right.$ day) ${ }^{36}$ and of the EPIC study (372 mg/day) ${ }^{37}$ and similar to that of the United States (189.7 $\mathrm{mg} /$ day) ${ }^{38}$. The main food sources for the intake of this class were fruits in the two European countries $^{34,36}$ and tea in the US ${ }^{38}$, while in Brazil legumes were the most important.

Numerous studies have reported benefits of flavonoid intake in the diet. The ingestion of a single dose (370 mg/day) showed a significant reduction in blood pressure ${ }^{39}$. In women over 65 it was noted that, after drinking up to three cups of tea for four weeks, there was a decrease in the prevalence of carotid plaques ${ }^{40}$. The intake of genistein and daidzein, from soya, appears to reduce the incidence of prostate and breast cancer in humans ${ }^{17}$.

Other phenolics had a low intake by the Brazilian population $(7.16 \mathrm{mg} /$ day) compared with Spain $(73 \mathrm{mg} / \text { day })^{35}$ and France $(41 \mathrm{mg} / \text { day })^{37}$.

The groups of fruit and vegetables constituted important sources of total phenolics and subclasses in studies done in other countries ${ }^{21,34,36}$. However, in Brazil less than 10\% of the population reaches the consumption recommendation of the $\mathrm{WHO}$ of $400 \mathrm{~g}$ of fruits and vegetables per day ${ }^{25,41}$. The daily consumption of these food groups according to WHO recommendation would result in a $68 \%$ increase in the intake of phenolics by the Brazilian population. Besides that, it would also result in a greater intake of vitamins, minerals and fibers that already have their essentialities described in human organism ${ }^{42}$.

It is worth noting that, as recommended by the Food Guide for the Brazilian Population ${ }^{43}$, consumption of food in natura or minimally 
processed must compose the base of diet for bringing greater benefits to health. Foods that undergo processing, especially those involving exposure to high temperatures or cold, usually show losses in their phenolic content ${ }^{44}$.

The teas were also observed among the main sources of compounds in other countries ${ }^{34-37}$, in addition to having its intake inversely related to the prevention of various diseases ${ }^{40,45,46}$. Nevertheless, the importance of the beverage for consumption of phenolics in Brazil can be considered low. The daily intake of $180 \mathrm{~mL}$ of mate tea (1 medium cup), for example, would provide approximately $33 \mathrm{mg}$ of phenolics. However, in this study it was found that the contribution of mate tea for consumption of phenolics of the Brazilian diet was six times smaller.

The higher intake of phenolic compounds for males was also found in French population ${ }^{36}$, however regarding the variable education there are differences between the studies. In the French cohort, the population with higher education was the one with higher intake of total compounds, mainly by high intake of flavonoids ${ }^{36}$. In Brazil, this population was the largest consumer of flavonoids and other phenolics, but had a low total intake due to low intake of phenolic acids.

In France a study conducted in a population aged 45 to 60 found no significant differences in consumption in relation to age $^{36}$. On the other hand, in Brazil was found that elderly people and adults had a greater intake of total phenolics. A likely reason for this result is the consumption of coffee, fruits and vegetables by these populations. Coffee was the most prevalent item in the diet of the elderly, being $32 \%$ higher than in adolescents, approximately. In addition, this population was the only one to have two fruits among the 20 most consumed foods ${ }^{25,47}$. Adults had a coffee consumption $25 \%$ higher than teenagers, approximately ${ }^{25}$. Coffee is known to possess large quantities of phenolic compounds, especially of the class of phenolic acids, being considered the major dietary source of hydroxycinnamic acids ${ }^{48}$.
With regard to household situation, the highest consumption of phenolics by the population living in rural areas can be attributed, possibly, to the highest intake of legumes, cereals and fruits groups, being $17.0 \%, 25.1 \%$ and $27.4 \%$ higher compared to urban areas. It was also noted that the consumption of acai berry by the rural population was three times higher than that observed in the urban population and it may be correlated with the highest consumption of flavonoids by these individuals.

With regard to geographic region, the northeast, the largest consumer of phenolic, stood up due to the consumption of cereals and products, especially corn that presented consumption six times higher than the average of the other regions. One can also verify that the north region showed consumption of acai berry expressively higher than the average of the other regions, which may be attributed to the higher intake of flavonoids by this population. For the income bands it was noted that the intermediate bands had a higher consumption or have been among the largest consumers in all food groups, especially the beverages. It is noteworthy that the highest income group had higher intake of fruits and cocoa-based products, which can be correlated to the higher consumption of flavonoids.

With regard to the use of phenolic compounds according to the nutritional status it was verified that there were no significant differences among the eutrophic and overweight population. Thus, the amount of food consumed can, possibly, be related to the amount of total phenolic compounds consumed. Regarding the consumption of the population with overweight it was verified that lifestyles harmful to health such as lack of physical exercise, smoking and obesity has been related to higher consumption of food and, mainly, coffee, with reflection in the increase of phenolic acids intake ${ }^{21}$.

\section{CONCLUSION}

The estimated intake of total phenolic compounds by the Brazilian population can be 
considered low compared with other countries and can be attributed especially to the low intake of food from the group of fruits and vegetables. In addition, it was verified that the main foods that contributed to the intake of phenolics by the Brazilian population were those that presented high consumption per capita as coffee, beans, corn and rice. Thus, it is highlighted the importance of the increase in the consumption of food from the groups of fruits and vegetables, in order to increase the phenolic contribution in the Brazilian diet.

\section{COLLABORATORS}

VG CORRÊA was responsible for the collection and analysis of data, as well as for the elaboration of the article. C TURECK and G LOCATELLI contributed to the analysis and discussion of data. RM PERALTA was responsible for the conception, data analysis and writing of the final version of the article. EA KOEHNLEIN was responsible for the conception, guidance, data analysis and elaboration of the article. All authors participated in the review of the final version of the manuscript.

\section{REFERENCES}

1. Stea TH, Mansoor MA, Wandel M, Uglem S, Frolich W. Changes in predictors and status of homocysteine in young male adults after a dietary intervention with vegetables, fruits and bread. Eur J Nutr. 2008; 47(4):201-9. http://dx.doi.org/10.1007/s00394008-0714-y

2. Heidemann $C$, Schulze $M B$, Franco $O H$, van Dam RM, Mantzoros CS, Hu FB. Dietary patterns and risk of mortality from cardiovascular disease, cancer, and all causes in a prospective cohort of women. Circulation. 2008; 118(3):230-7. http://dx.doi.org/ 10.1161/CIRCULATIONAHA. 108.771881

3. Hanhineva K, Törrönen R, Bondia-Pons I, Pekkinen $J$, Kolehmainen M, Mykkänen $\mathrm{H}$, et al. Impact of dietary polyphenols on carbohydrate metabolism. Int J Molecular Sci. 2010; 11(4):1365-402. http:// dx.doi.org/10.3390/ijms11041365

4. Neveu $V$, Perez-Jiménez J, Vos F, Crespy $V$, du Chaffaut L, Mennen L, et al. Phenol-Explorer: An online comprehensive database on polyphenol contents in foods. Database. 2010. http://dx.doi. org/10.1093/database/bap024
5. Agarwal A, Makker K, Sharma R. Clinical relevance of oxidative stress in male factor infertility: An update. Am J Reprod Immunol. 2008; 59(1):2-11. http://dx.doi.org/10.1111/j.1600-0897.2007.00 559.x

6. Hayashi M. Oxidative stress in developmental brain disorders. Neuropathology. 2009; 29(1):1-8. http:// dx.doi.org/10.1111/j.1440-1789.2008.00888.x

7. Valko M, Izakovic M, Mazur M, Rhodes CJ, Telser J. Role of oxygen radicals in DNA damage and cancer incidence. Mol Cell Biochem. 2004; 266(1-2):37-56.

8. Valko M, Leibfritz D, Moncol J, Cronin MT, Mazur $\mathrm{M}$, Telser J. Free radicals and antioxidants in normal physiological functions and human disease. Int J Biochem Cell Biol. 2007; 39(1):44-84. http://dx. doi.org/10.1016/j.biocel.2006.07.001

9. Murphy MM, Barraj LM, Herman D, Bi X, Cheatham R, Randolph RK. Phytonutrient intake by adults in the United States in relation to fruit and vegetable consumption. J Am Diet Assoc. 2011; 112(2):222-9. http://dx.doi.org/10.1016/j.jada.2011.08.044

10. Pérez-Jiménez J, Arranz S, Tabernero M, Díaz-Rubio ME, Serrano J, Goñi I, et al. Updated methodology to determine antioxidant capacity in plant foods, oils and beverages: Extraction, measurement and expression of results. Food Res Int. 2008; 41(3):27485. http://dx.doi.org/10.1016/j.foodres.2007.12.0 04

11. Chun OK, KIM D, Smith N, Schroeder D, Han JT, Lee CY. Daily consumption of phenolics and total antioxidant capacity from fruit and vegetables in the American diet. J Sci Food Agric. 2005; 85(10):1715-24. http://dx.doi.org/10.1002/jsfa. 2176

12. Hervert-Hernández D, García OP, Rosado JL, Goñi I. The contribution of fruits and vegetables to dietary intake of polyphenols and antioxidant capacity in a Mexican rural diet: Importance of fruit and vegetable variety. Food Res Int. 2011; 44(5):1182-9. http://dx.doi.org/10.1016/j.foodres. 2010.09.021

13. Quiñones M, Miguel M, Aleixandre A. Beneficial effects of polyphenols on cardiovascular disease. Pharmacol Res. 2013; 68(1):125-31. http://dx.doi. org/10.1016/j.phrs.2012.10.018

14. McKay DL, Chen CY, Zampariello CA, Blumberg JB. Flavonoids and phenolic acids from cranberry juice are bioavailable and bioactive in healthy older adults. Food Chem. 2015; 168(1):233-40. http:// dx.doi.org/10.1016/j.foodchem.2014.07.062

15. de Kok TM, van Breda SG, Manson MM. Mechanisms of combined action of different chemo preventive dietary compounds: A review. Eur J Nutr. 2008; 47(2):51-9. http://dx.doi.org/10.1007/s00394-0082006-y 
16. Del Rio D, Rodriguez-Mateos A, Spencer JP, Tognolini M, Borges G, Crozier A. Dietary (poly)phenolics in human health: Structures, bioavailability, and evidence of protective effects against chronic diseases. Antioxid Redox Signal. 2013; 18(14):1818-92. http://dx.doi.org/10.1089/ ars.2012.4581

17. Crozier A, Jaganath IB, Clifford MN. Dietary phenolics: Chemistry, bioavailability and effects on health. Nat Prod Rep. 2009; 26(8):1001-43. http:// dx.doi.org/10.1039/b802662a

18. Nardini M, Ghiselli A. Determination of free and bound phenolic acids in beer. Food Chem. 2004; 84(1):137-43. http://dx.doi.org/10.1016/S0308-8 146(03)00257-7

19. Carocho M, Ferreira ICFR. A review on antioxidants, prooxidants and related controversy: Natural and synthetic compounds, screening and analysis methodologies and future perspectives. Food Chem Toxicol. 2013; 51:5-25. http://dx.doi.org/10.1016/ j.fct.2012.09.021

20. Pérez-Jiménez J, Neveu V, Vos F, Scalbert A. Identification of the 100 richest dietary sources of polyphenols: An application of the phenol-explorer database. Eur J Clin Nutr. 2010; 64(3):112-20. http:// dx.doi.org/10.1038/ejcn.2010.221

21. Zamora-Ros R, Rothwell JA, Scalbert A, Knaze V, Romieu I, Slimani N, et al. Dietary intakes and food sources of phenolic acids in the European Prospective Investigation into Cancer and Nutrition (EPIC) study. Br J Nutr. 2013; 110(8):1500-11. http:// dx.doi.org/10.1017/S0007114513000688

22. Arabbi PR, Genovese MI, Lajolo FM. Flavonoids in vegetable foods commonly consumed in Brazil and estimated ingestion by the Brazilian population. J Agric Food Chem. 2004; 52(5):1124-31.

23. Faller AFK, Fialho E. Disponibilidade de frutas e hortaliças consumidas no Brasil. Rev Saúde Pública. 2009; 43(2):211-8.

24. Koehnlein EA, Bracht A, Nishida VS, Peralta RM. Total antioxidant capacity and phenolic content of the Brazilian diet: A real scenario. Int J Food Sci Nutr. 2014; 65(3):293-8. http://dx.doi.org/10.3109/ 09637486.2013 .879285

25. Instituto Brasileiro de Geografia e Estatística. Pesquisa de Orçamentos Familiares 2008-2009: análise do consumo alimentar pessoal no Brasil. Rio de Janeiro: IBGE; 2011.

26. Sawaya AL, Tucker K, Tsay R, Willett W, Saltzman E, Dallal GE, et al. Evaluation of four methods for determining energy intake in young and older women: Comparison with doubly labeled water measurements of total energy expenditure. Am J Clin Nutr. 1996; 63(4):491-99.
27. Subar AF, Kipnis $V$, Troiano RP, Midthune D, Schoeller DA, Bingham $S$, et al. Using intake biomarkers to evaluate the extent of dietary misreporting in a large sample of adults: The OPEN study. Am J Epidemiol. 2003; 158(1):1-13.

28. Rostagno MA, Manchón N, D’Arrigo M, Guillamón E, Villares A, García-Lafuente A, et al. Fast and simultaneous determination of phenolic compounds and caffeine in teas, mate, instant coffee, soft drink and energetic drink by high-performance liquid chromatography using a fused-core column. Anal Chim Acta. 2011; 685(2):204-11. http://dx.doi.org/ 10.1016/j.aca.2010.11.031

29. Ordoñez AAL, Gomez JD, Vattuone MA, Isla MI. Antioxidant activities of Sechium edule (Jacq.) Swartz extracts. Food Chem. 2006; 97(3):452-58. http://dx.doi.org/10.1016/j.foodchem.2005.0 5.024

30. Biesaga M, Pyrzynska K. Liquid chromatography/ tandem mass spectrometry studies of the phenolic compounds in honey. J Chromatogr. 2009; 1216(38):6620-6. http://dx.doi.org/10.1016/j. chroma.2009.07.066

31. de Onis M, Onyango AW, Borghi E, Siyam A, Nishida C, Siekmann J. Development of a WHO growth reference for school-aged children and adolescents. Bull World Health Organ. 2007; 85(9):660-7.

32. World Health Organization. Obesity: Preventing and managing the global epidemic. Geneva: WHO; 1998 [cited 2014 June 19]. Available from: http:// www.who.int//

33. Nutrition Screening Initiative. Interventions manual for professionals caring for older Americans. Washington: Nutrition Screening Initiative; 1992.

34. Tresserra-Rimbau A, Medina-Remón A, PérezJiménez J, Martínez-González MA, Covas MI, Corella D, et al. Dietary intake and major food sources of polyphenols in a Spanish population at high cardiovascular risk: The PREDIMED study. Nutr Metab Cardiovasc Dis. 2013; 23(10):953-9. http:// dx.doi.org/10.1016/j.numecd.2012.10.008

35. Ovaskainen ML, Törrönen R, Koponen JM, Sinkko $\mathrm{H}$, Hellström J, Reinivuo H, et al. Dietary intake and major food sources of polyphenols in Finnish adults. J Nutr. 2008; 138(3):562-66.

36. Pérez-Jiménez J, Fezeu L, Touvier M, Arnault N, Manach C, Hercberg S, et al. Dietary intake of 337 polyphenols in French adults. Am J Clin Nutr. 2011; 93(6):1220-28. http://dx.doi.org/10.3945/ajcn. 110.007096

37. Zamora-Ros R, Knaze V, Luján-Barroso L, Romieu I, Scalbert A, Slimani N, et al. Differences in dietary intakes, food sources and determinants of total flavonoids between Mediterranean and nonMediterranean countries participating in the 
European Prospective Investigation into Cancer and Nutrition (EPIC) study. Br J Nutr. 2013; 109(8):14981507. http://dx.doi.org/10.1017/S000711451200 3273

38. Chun OK, Chung SJ, Song WO. Estimated dietary flavonoid intake and major food sources of U.S. adults. J Nutr. 2007; 137(5):1244-52.

39. Balzer J, Rassaf T, Heiss C, Kleinbongard P, Lauer T, Merx $M$, et al. Sustained benefits in vascular function through flavanol-containing cocoa in medicated diabetic patients a double-masked, randomized, controlled trial. J Am Coll Cardiol. 2008; 51(22):2141-9. http://dx.doi.org/10.1016/ j.jacc.2008.01.059

40. Debette S, Courbon D, Leone N, Gariépy J, Tzourio C, Dartigues JF, et al. Tea consumption is inversely associated with carotid plaques in women. Arterioscler Thromb Vasc Biol. 2008; 28(2):353-59.

41. World Health Organization. Diet, nutrition and the prevention of chronic diseases. Geneva: WHO; 2003 [cited 2014 Dec 20]. Technical Report Series, $n^{\circ}$ 916. Available from: http://whqlibdoc.who.int/ trs/WHO_TRS_916.pdf

42. Lee HS, Cho YH, Park J, Shin HR, Sung MK. Dietary intake of phytonutrients in relation to fruit and vegetable consumption in Korea. J Acad Nutr Diet. 2013; 113(9):1194-99. http://dx.doi.org/10.1016/ j.jand.2013.04.022

43. Brasil. Ministério da Saúde. Guia alimentar para a população brasileira. Brasília: Ministério da Saúde; 2014 [acesso 2014 dez 20]. Disponível em: http:// portalsaude.saude.gov.br/images/pdf/2014/
novembro/05/Guia-Alimentar-para-a-popbrasiliera-Miolo-PDF-Internet.pdf

44. Rothwell JA, Medina-Remón A, Pérez-Jiménez J, Neveu V, Knaze V, Slimani N, et al. Effects of food processing on polyphenol contents: A systematic analysis using Phenol-Explorer data. Mol Nutr Food Res. 2014; 59(1):160-70. http://dx.doi.org/ 10.1002/mnfr.201400494

45. Tomata Y, Kakizaki M, Nakaya N, Tsuboya T, Sone T, Kuriyama S, et al. Green tea consumption and the risk of incident functional disability in elderly Japanese: The Ohsaki Cohort 2006 Study. Am J Clin Nutr. 2012; 95(3):732-9. http://dx.doi.org/10.3945/ ajcn. 111.023200

46. Arab L, Khan F, Lam H. Tea consumption and cardiovascular disease risk. Am J Clin Nutr. 2013; 98(6):1651-9. http://dx.doi.org/10.3945/ajcn.1 13.059345

47. Souza AM, Pereira RA, Yokoo EM, Levy RB, Sichieri R. Alimentos mais consumidos no Brasil: Inquérito Nacional de Alimentação 2008-2009. Rev Saúde Pública. 2013; 47(1):190-9. http://dx.doi.org/10. 1590/S0034-89102013000700005

48. Mullen W, Nemzer B, Stalmach A, Ali S, Combet E. Polyphenolic and hydroxycinnamate contents of whole coffee fruits from China, India, and México. J Agric Food Chem. 2013; 61(22):5298-309. http:// dx.doi.org/10.1021/jf4003126

Received: August 12, 2014 Final version: January 5, 2015 Approved: January 12, 2015 